\title{
Editorial v. 28, n. 1 (2016)
}

Ao escrever esse editorial, não pudemos ignorar o que acontece à nossa volta hoje no Brasil e, mais perto de nós, na UFF. O escrevemos três dias depois dos "protestos" nas ruas contra a corrupção no governo federal e a favor do impedimento (sim, em português claro, sem sotaque estrangeiro em tempos de internacionalização) à atual presidente eleita do país. O escrevemos no dia em que o Conselho Universitário da UFF aprovou, em mais uma de suas polêmicas votações, a entrada da Empresa Brasileira de Serviços Hospitalares no Hospital Universitário Antônio Pedro. Tempos difíceis.

$\mathrm{O}$ escrevemos comemorando a edição de mais um número da Fractal que nunca sabemos se virá à luz ou não porque os editais de financiamento seguem suspensos. Este número deve muito à própria Fractal e ao interesse que polariza, aos seus exemplares vendidos em uma tarde-noite alegre na Psicologia da UFF.

Hoje chove e o céu se faz cinza lá fora. Ao lado da chuva de verão, as chuvas de denuncismos, caça às bruxas, moralismos de quem se arvora em defensor do país e do povo para consertar o país, eliminar a corrupção, prender, caçar, fichar, para voltar a crescer economicamente, embora se continue a pensar do mesmo jeito conhecido e requentado de sempre. Tempos de dengue, zika e chikungunya, mas também de virais fascismos, bancadas militares ou fundamentalistas, ódios e judicialização da vida. Tempos de heróis bem-apessoados e de terno caro que combatem marajás, já vimos esse filme em algum lugar? Se defendermos a liberdade, somos acusados de defender bandidos; se defendemos o respeito aos direitos humanos, somos acusados de defender bandidos; se lembramos a importância da democracia, somos acusados de conivência com o crime, de sermos intelectuais alienados, que protegem criminosos comunistas e não vêem o que se passa à volta. Se pedimos que o tratamento às denúncias e apurações seja equitativo e menos parcial, estamos do lado de analfabetos oportunistas, que falam e escrevem errado, que esqueceram suas origens e ideais, que só querem enriquecer; ou de mulheres burras, que não sabem o que fazem e nem o que dizem e que devem cair. Seria uma cegueira branca? Ou uma amnésia em relação ao passado recente ainda muito próximo a ponto de se poder sentir seu cheiro de morte e de sangue, de porão e de choque, de "cale-se" ou morra ou de "fale" ou morra? Não detemos a verdade porque o que queremos é que não haja uma verdade e uma certeza. A verdade não é uma opinião correta. Aliás, a aletheia pré-socrática era desvelamento, espanto, estranhamento, abertura. Nunca uma opinião moral e jamais uma operação. Tempos difíceis.

Não estamos certos nem errados porque não queremos a polarização entre certo e errado. Não queremos o lugar de quem tem razão e vai corrigir as coisas. Só queremos que as razões e desrazões possam ter espaço lado-a-lado para serem expressas, debatidas sem medo, isso mesmo, sem medo. Não defendemos este ou aquele lado, apenas não queremos pessoalizar os graves problemas brasileiros, suas inúmeras, antigas e recentes violências, muito menos identificar bodes expiatórios onde espetaremos nossas facas e nos sentiremos fazendo justiça. Vamos olhar para tudo isto como algo que nos diz respeito, a todos nós, ao modo como temos vivido, à nossa história. Não vamos olhar como se fosse um corpo estranho e invasor que deve ser combatido com antibióticos que, sempre traiçoeiros, podem acabar por fortalecer o que prometem combater.

A atmosfera de temor, de ameaça, de crise, de destruição do país, do risco-país elevado que afasta investidores, mantém vivo o terror. E o medo é traiçoeiro. Pode fazer com que algo mais violento advenha, na roupagem de solução definitiva e salvação. Também já vimos esse filme antes. Divididos em vilões e vítimas, bons e maus, honestos e desonestos, não avançamos.

Saúde mental, corpo, Aids, mulher, racismo, TDAH, regimes de verdade, por que os psicólogos e outros artesãos "de Humanas" insistem em continuar pensando e falando sobre esses temas? Por que não resolvem logo o que fazer, por que debatem tanto sobre tudo, por que são os chatos de plantão que não chegam rapidamente a conclusões e por que não assumem logo um dos lados da polaridade, ou o bem ou o mal? Seria mais prático, mais rápido, mais limpo (passar o rodo e lavar, aliás, estão em voga). Por que insistem em pensar como é a vida dos que seguem sem serem convidados para as festas e banquetes da vida bem-sucedida; dos que vivem sem serem magros, ricos, sarados, poderosos, acompanhados, turistas, radicais, fortes e saudáveis? Para que pensar os "desviantes", os inadequados, os irrequietos, os que têm dúvidas, os fracassados, os que estão em crise, os que dizem não, os que seguem desejantes, os que sonham, os artistas, os que contemplam, os internos, os medicalizados, os que são varridos do mapa citadino porque nunca farão parte dos Jogos?

Bem, porque sim. Então que esse número possa, caro (a) leitor (a), te chatear bastante, é o que desejamos. 